Foreign Direct Investment as Technology Transferred: Some Panel Evidence from the Transition Economies

\author{
By: Nauro F. Campos and Yuko Kinoshita
}

William Davidson Working Paper Number 438

January 2002 


\title{
Foreign Direct Investment as Technology Transferred: Some Panel Evidence from the Transition Economies
}

\author{
Nauro F. Campos* \\ Department of Economics, \\ University of Newcastle, \\ Centre for Economic Policy Research, London, and \\ the William Davidson Institute, University of Michigan. \\ Yuko Kinoshita** \\ Department of Economics, \\ Hunter College, City University of New York, \\ Centre for Economic Policy Research, London, \\ and the William Davidson Institute, University of Michigan.
}

This version: January 2002

Abstract: Although the theoretical literature has identified various sizeable benefits from foreign direct investment inflows (FDI), the empirical literature has been unable to establish a positive and significant impact of FDI on the rates of economic growth of host countries. One reason for this difficulty is that theory equates FDI to technology transferred, while in most countries and regions of the world FDI encompasses an array of arrangements that goes well beyond pure technology transfer. This paper tests for the effects of FDI on growth in a set of countries in which FDI is purer technology transferred: the 25 Central and Eastern European and former Soviet Union transition countries between 1990 and 1998. Our main finding is that, in this more appropriate setting, FDI has a positive and significant impact on economic growth as theory predicts.

Keywords: Foreign Direct Investment, economic growth, transition economies. JEL classification: F21, O16, O23, C33, P27.

We thank Francesco Giovannoni, Gordon Hanson, Boyan Jovanovic, James Levinsohn, Peter Neary, Gérard Roland, Daniel Seidmann, John Sutton, Richard Upward, Katharine Wakelin, Bernard Yeung, two anonymous referees and seminar participants at the University of Newcastle, $2^{\text {nd }}$ MDT Meetings (Rio de Janeiro), $6^{\text {th }}$ CEPR-WDI Transition Conference (Portoroz), GEP Conference (Nottingham) and CEPR-CREI Workshop on FDI (Barcelona) for valuable comments on previous versions. We also thank Aurelijus Dabušinskas, Anna Ratcheva, Evis Sinani and Dana Žlábková for excellent research assistance, and the William Davidson Institute at the University of Michigan for the hospitality. The usual disclaimer applies.

* Department of Economics, University of Newcastle, Newcastle upon Tyne, NE1 7RU, United Kingdom. E-mail: n.f.campos@ncl.ac.uk

** Department of Economics, Hunter College, City University of New York, 695 Park Avenue NY, NY 10021, USA. E-mail: yuko.kinoshita@hunter.cuny.edu 


\section{Introduction}

Although the positive impact of foreign direct investment inflows (FDI) on economic growth seem to have recently acquired the status of stylised fact, a closer examination of the attendant empirical evidence disappoints all but the most fervent believer. Despite the numerous alleged benefits of FDI to the host economy, the empirical literature has not succeeded in establishing a significant positive impact of FDI on the rates of economic growth of host countries. ${ }^{1}$ Borenzstein, De Gregorio and Lee (1998) find that a positive impact of FDI on growth is obtained only for those countries that have accumulated a minimum threshold stock of human capital. Lensink and Morrissey (2001) also find a positive impact but caution that this result is not "entirely robust." Focusing solely on OECD countries, de Mello (1999) finds that FDI is growth-enhancing only for countries in which domestic and foreign capital are complements. Yet Lipsey (2000) reports that there is little evidence on the impact of FDI on domestic capital formation. Blomstron, Lipsey and Zejan (1994) find that FDI has a positive impact on growth mostly in what these authors define as "low-quality data" countries. And Saltz (1992) even finds that FDI has a negative impact on growth. As de Melo puts it: "whether FDI can be deemed to be a catalyst for output growth, capital accumulation, and technological progress seems to be a less controversial hypothesis in theory than in practice" (1999, p. 148).

One possible reason for this discrepancy between economic theory and econometric evidence is that the former tends to equate FDI to technology transferred, while in most countries and regions of the world FDI encompasses an array of arrangements that goes well beyond pure technology transfer. The transition economies may be the right context in this case. At the onset of the transition (from centrally planned to market economy), these

\footnotetext{
${ }^{1}$ See Blomstron (1992), de Mello (1997), and Hanson (2001) for surveys.
} 
economies were far away from the international technological frontier. Yet, differently from many developing countries, they started out with a complete industrial structure and a relatively educated work force. Other advantages of these economies are the proximity to richer European markets and that most embarked on comprehensive privatisation processes at the time when FDI was starting to peak on a world-wide scale. Hence transition economies have the "enabling environment" that lacks in many developing countries, but share their long distance away from the world technological frontier. It is this combination of potential gains and favourable conditions to realise these gains that, we argue, makes the transition experience an excellent testing ground for the impacts of FDI on growth.

The objective of this paper is to assess empirically the impact of FDI on economic growth in the 25 Central and Eastern European and former Soviet Union transition countries between 1990 and 1998. Our main finding is that, in this setting, FDI has the positive and statistically significant impact on economic growth that theory predicts.

The paper by Borenzstein, De Gregorio and Lee (1998) highlights the role of FDI as an important vehicle of economic growth. Their main result is that FDI contributes to growth only when there is sufficient absorptive capability in the host economy. Reaching a minimum threshold of human capital reflects this capability. Empirically, this is captured by an interaction term between FDI and human capital (measured as enrolment rates in secondary school). The authors find that although FDI itself tends to be statistically insignificant as an independent variable in growth regressions, the interaction term tends to be statistically significant. In this paper, we also find that FDI is an important factor explaining economic growth in transition economies. However, the effect of FDI on economic growth does not necessarily depend on the host country's absorptive capacity since the level of human capital 
in transition economies is already above the minimum threshold. In this sense, our paper complements the finding of Borenzstein et al. (1998).

The paper is organised as follows. The next section provides the theoretical motivation for our empirical results. Section III discusses the data set. Section IV presents our core econometric results. Section V reports various sensitivity analyses to help gauge the robustness of our core results. Section VI concludes.

\section{Theoretical Considerations}

In Solow-type standard neoclassical growth models, FDI is traditionally conceived as an addition to the capital stock of the host economy (e.g., Brems, 1970). In this view, there are no substantial differences between domestic and foreign capital. More importantly, the impact of FDI on growth is similar to that of domestic capital. With diminishing returns to capital, FDI has no permanent impact on the growth rate. FDI will have, however, a short-run impact on growth, which depends on the transitional dynamics to the steady-state growth path. ${ }^{2}$

In endogenous growth models, the potential role of FDI is greater. There are a number of channels through which FDI permanently affects the growth rate. A convenient way to think about these effects is to specify how FDI affects each argument in the production function. FDI can affect output by increasing the stock of capital. However, this impact is likely to be small under the assumption of perfect substitutability. Although the empirical evidence on this matter is mixed (Hanson, 2001), if foreign and domestic capital are

\footnotetext{
${ }^{2}$ For surveys of the literature on economic growth, see Barro and Sala-i-Martin (1995) and Aghion and Howitt (1998). For surveys of the methodology and empirical evidence, see Temple (1999) and Durlauf and Quah (1999). For a survey of the literature on growth in transition, see Campos and Coricelli (forthcoming).
} 
complements the final impact of FDI on aggregate output will be larger as a result of these externalities. Further, if foreign capital is treated differently from domestic capital, say, by way of expanding the variety of intermediate goods and capital equipments, FDI can raise productivity in the host country (Borensztein et al., 1998).

FDI also affects labour through job creation, although this may be limited to the short run. However, the more important and long-run effect of FDI is the transfer of technology and know-how that are embodied in human capital. Consider when foreign investment is carried out in activities in which the host economy has limited previous experience. In this case FDI will entail important knowledge transfer in terms of training, skill acquisition, new management practices and organisational arrangements. Thus, labour in efficiency units will have a greater contribution to output growth.

Alternatively, FDI may lead to technological change that is neutral to both capital and labour: FDI directly raises the level of technology in the host economy. That can be for a variety of mechanisms. One mechanism through which FDI affects growth is learning. FDI diffuses knowledge about production methods, product design and new organisational and managerial techniques. In this light, imitation becomes a crucial element. FDI may also enhance the productivity of domestic R\&D (Research and Development) activities.

In what follows, we estimate five specifications that are standard in the growth and FDI literatures and capture the channels discussed above. They are aggregate production functions derived from the augmented Solow model (Mankiw, Romer and Weil, 1992), from the model developed by Borensztein, de Gregorio and Lee (1998) and that from Easterly (2001). Let us comment on each of these. 
The model developed by Borensztein, de Gregorio and Lee (1998) yields the following basic specification (BGL1):

$$
\mathrm{y}=\mathrm{f}(\mathrm{y} 0, \mathrm{hk}, \mathrm{fdi}, \mathrm{infl}, \text { govc, war, buroqual) }
$$

where y is real GDP growth, y0 is initial GDP, hk is human capital, fdi is foreign direct investment, infl is the inflation rate, govc is government consumption as a percentage of GDP, war is a dummy variable for war and buroqual is an institutional variable capturing the quality of the bureaucracy. ${ }^{3}$ The model predicts that the effects of initial income, inflation, government consumption and war are negative, while those of human capital, FDI and institutions are positive.

We estimate two variants of the Borensztein, de Gregorio and Lee (1998) model. One is as follows:

$$
\mathrm{y}=\mathrm{f}(\mathrm{y} 0, \mathrm{hk}, \mathrm{fdi}, \text { infl, govc, war, buroqual, inv) }
$$

where investment is included. This allows us to examine the relationship between foreign and domestic investment. As noted, these authors report that the coefficient on FDI itself is not statistically significant, even when an interaction term between FDI and human capital is introduced (the latter is statistically significant and forms the basis for their result). The second variant we report is the specification that includes this interaction term.

The augmented Solow specification from Mankiw et al. (1992) will have the following form (MRW):

\footnotetext{
${ }^{3}$ Due to data availability, there are some differences between the original specification and the one we use in this paper. There were dummy variables for Latin American and African countries that are not present in our specification. Originally, it also contained variables reflecting the number of assassinations per capita, the extent of political freedoms and the occurrence of civil wars. To substitute for these, we use a dummy variable for internal and external armed conflicts (war). The institutional variables in the original specification are not available, thus here we use a measure of the quality of the bureaucracy. We were not able to find panel data for the black market premium on the exchange rate for our sample of transition economies.
} 


$$
y=f(y 0, \text { inv }, \text { pop, hk, fdi })
$$

where, for the variable not defined above, pop is population growth. Notice that because FDI is absent from the original formulation we have to modify it in the standard way by specifying technological change as a function of FDI. ${ }^{4}$ The model predicts that the effects of initial income and of population growth are negative, while those of investment, human capital and FDI are positive.

The last econometric model we use in this paper is the outcome of a search for a specification that is able to highlight the main determinants of economic growth in the crosscountry setup. The model postulated by Easterly (2001) is as follows (EAST):

$$
\mathrm{y}=\mathrm{f}(\mathrm{y} 0, \mathrm{hk}, \mathrm{fdi}, \text { infl, infra, oecdgrowth) }
$$

where, for the variables not defined above, infra is a proxy for the quality of the infrastructure in the host economy and oecdgrowth is a proxy for international activity. ${ }^{5}$ The predictions are that the effects of initial income and inflation are negative while those of human capital, FDI and infrastructure and OECD growth are positive.

\section{Data Issues}

The data set assembled for this paper has yearly observations for 25 transition economies in Central Europe and in the former Soviet Union covering the period 1990 to 1998 . We collected data on annual per capita GDP growth rates, initial GDP per capita, basic education gross enrolment ratio, government consumption as a percentage of GDP, FDI, gross domestic

\footnotetext{
${ }^{4}$ The same modification is done for the Easterly (2001) specification.

${ }^{5}$ The Easterly specification also contains two variables for which we were unable to obtain panel data for the transition economies. One is the black market premium on the exchange rate and the other is the real exchange rate.
} 
fixed investment as a percentage of GDP, population growth, and government expenditures as a percentage of GDP.

Table 1 has the correlation matrix. Notice that the largest correlation coefficients involving economic growth are with the index of external liberalization (from Berg et al., 1999), with the dummy variable for armed conflict (war) and with FDI, in descending order. It is also worth noting that the highest correlation coefficients involving FDI are with human capital (basic education enrolment ratio), the index of external liberalization and the index of the quality of the bureaucracy.

One of the defining stylized facts of the first ten years of the transition from centrally planned to market economy is the massive output fall. Output fell in every single country, with no exceptions, and it took longer than expected to recover. As an indicator of the severity of this decline, notice that real GDP in 1999 surpassed it 1989 level in just two of the 25 economies in Central Europe and in the former Soviet Union (these are Poland and Slovenia). Figure 1 shows economic performance in terms of real GDP for three regions: Baltic States (Baltics), Central and Eastern European countries (CEEC), and other former Soviet Union countries (CIS). It is worth noting that CEEC experienced output declines that were much smaller than the ones observed in the CIS economies, at a later date. And finally, there seems to be a "Baltic puzzle": although the former Soviet Republics Estonia, Latvia and Lithuania all had output contractions comparable to CIS countries, their recovery was faster.

A major caveat in assessing the depth of the output fall is that it refers to official estimates and thus ignores the shadow economy or informal sector. The latter has grown very rapidly in the early transition years and the way researchers have measured it is through 
electricity consumption as a more encompassing measure of economic activity. Notice that the output fall also obtains using an electricity consumption index (Johnson, Kaufmann and Shleifer, 1997). For example, in its lowest point the GDP index of Visegrad countries ${ }^{6}$ was 85 per cent of its 1990 GDP level while the corresponding value of the electricity consumption index was 90 per cent. At the other extreme, the trough values of GDP and electricity consumption indexes for the Central Asian countries were only 46 and 62 per cent, respectively. In all countries, total activity seems to have declined less than what the official figures suggest. Yet the output fall obtains irrespective of the measure chosen.

Let us turn to the trend and pattern of foreign direct investment in these economies. We look at four different measures of FDI: cumulative net FDI per capita, annual net FDI per capita, FDI as a share of GDP and FDI relative to gross domestic investment (Table 2). In all four measures, we find that FDI into transition economies have been constantly rising but their magnitude and importance remain highly unequal among the country subgroups. And in most cases, the pattern of dispersion is highly persistent in time. For example, in terms of cumulative per capita net FDI inflows transition economies fall into three groups and their relative position has no tendency to change during the period of analysis. The Vysegrad countries have maintained a leading position, with cumulative FDI inflow per capita reaching $\$ 700$ by 1997 . The Balkan, BUR, and Central Asian countries remained far behind as the amount of cumulative per capita FDI was just $\$ 100$ or less, while $\$ 500$ stock of per capita FDI in the Baltic countries placed these in between.

\footnotetext{
${ }^{6}$ We divided the sample in five groups for exposition purposes. The transition countries in ASIA are Armenia, Azerbaijan, Georgia, Kazakhstan, Kyrgyztan, Tajikistan, Turkmenistan and Uzbekistan. The BALKAN countries are Albania, Bulgaria, Croatia, Macedonia, Moldova and Romania. The BALTIC countries are Estonia, Latvia and Lithuania. The group called BUR comprises Belarus, Ukraine and Russia. The VISEGRAD countries are the Czech Republic, Hungary, Poland, Slovakia and Slovenia.
} 
The same patterns among country groups are detected in the figures of annual per capita FDI . Although these series have been more volatile, the relative position of countries with respect to new FDI inflows remains by and large the same. In 1997, average per capita FDI were $\$ 120$ and $\$ 160$ for Vysegrad and the Baltic countries respectively, while the other countries received less that $\$ 40$, and a gap of similar magnitude has prevailed since $1994 .^{7}$

The measure of net FDI relative to countries' GDP has been somewhat more dynamic since 1994 and hints that FDI is rapidly gaining importance not only in the Baltic countries but also in some Central Asian countries. For this latter group, the average rate of foreign direct investment went up from mere 0.5 in 1994 to almost 5 per cent of GDP in 1997. As a result, the group ranked second after the Baltics (6\%) and left behind even Vysegrad and Balkan countries (almost 3\%). Care should be exercised with these figures because of the different dynamics of the informal sector. As discussed above, the informal sector has grown fast in transition economies to the point that it accounts for more than half of national output in the most extreme cases (Johnson et al., 1997).

The FDI-to-domestic investment figures provide a very similar picture to that implied by the FDI-GDP ratios. The share of FDI in domestic investment has been rising in all the countries but the Vysegrad group, where the share has been relatively flat. Yet the levels achieved so far show a very dispersed pattern. In 1997, the FDI-to-domestic investment ratio ranged from 25 per cent in the Asian and Baltic countries, 18 per cent in the Balkans to 10 per cent in Vysegrad and 5 per cent in the BUR countries. Perhaps not surprisingly, BUR and Vysegrad countries were also the groups with the smallest gaps between their saving and investment rates, 0 and 2 percentage points respectively. In contrast, the gaps were 14, 11, and

\footnotetext{
7 See, e.g., Lankes and Venables (1996) and Meyer and Pind (1999).
} 
8 percentage points in Asia, Balkan, and the Baltic countries respectively. These significant gaps imply that the latter countries must use some external sources to finance investment. FDI is clearly one of such sources.

To summarise, the inflow of FDI to the region has been rising constantly as reflected by both relative and absolute FDI measures but the distribution of these flows is highly uneven and remains such, again, as implied by all these measures. Looking at individual countries, one finds that the largest recipients of FDI are, in descending order, Hungary and Poland, then Czech Republic and Russia. This ranking suggests that the determinants of FDI are rather different across transition economies. For instance, one conjecture is that the economic policies pursued in Hungary and Poland after 1989 is crucial in attracting attracts FDI. On the other hand, we expect that FDI is attracted to the Czech Republic by the generally favourable initial conditions. Finally, the reasons for FDI to Russia may have to do with the abundance of natural resources (oil and gas) in that country. This variety of determinants for FDI in transition should be kept in mind. ${ }^{8}$

\section{Econometric Results}

The objective of this section is to discuss our main set of econometric results for this paper. They refer to the impact of FDI on economic growth in transition economies. We report estimates for five standard specifications from the literature. We estimate aggregate production functions derived from the model developed by Borensztein, de Gregorio and Lee

\footnotetext{
${ }^{8}$ See Bevan and Estrin (2000) and Kinoshita and Campos (2001).
} 
(1998), from the augmented Solow model (Mankiw, Romer and Weil, 1992) and from Easterly (2001).

The transition generates difficulties for the estimation of these production functions for at least two reasons. One is that the transition marks a fundamental break in the way the economy is organized. The second is that the transition covers a very short period of time. In order to deal with these issues, the literature (on growth in transition) has opted for panel data instead of the more traditional cross-sectional approach. We are aware of the difficulties involved in this choice and subject our core results accordingly to a number of sensitivity tests in order to gauge their robustness vis-à-vis potential reverse causality, endogeneity and omitted variable bias (see Section 5 below).

Let us now turn to our set of core results. Table 3 shows OLS fixed-effects panel data estimates. The first column (BGL1) reports the basic specification proposed by Borensztein, De Gregorio and Lee (1998). A positive and significant coefficient of FDI suggests that per capita FDI is indeed an important determinant of economic growth in transition economies. On the other hand, human capital fails to have any impact on economic growth. The coefficient even carries a negative sign, although it is not significant. Lack of variation in the human capital variable is a possible reason for its statistical insignificance (although transition economies have high enrolment rates vis-à-vis developing countries, this variable varies little across transition economies).

The prediction of the neoclassical model holds for transition economies as a negative coefficient of initial income suggests. There seems to be a strong tendency for convergence. Other variables that are found to contribute to economic growth are low inflation rate, political stability reflected in the war dummy, and a well-functioning institutional framework 
as reflected in the quality of bureaucracy variable. Overall, the specification behaves satisfactorily for the transition economies with a few exceptions of human capital and government consumption. In particular, FDI is one of the key factors for economic growth for these countries.

As noted, in Borensztein et al. (1998), the coefficient on foreign direct investment by itself is not statistically significant. Because the adoption of new technology requires an educated labour force, these authors take into account a complementary relationship between FDI and schooling by including an interaction term. A positive sign on the interaction term of FDI and schooling supports the notion that FDI is able to generate a detectable beneficial impact on economic growth only for those countries in which the existing stock of human capital has reached a certain minimum threshold level.

For our sample of transition economies, FDI has a direct and positive impact on economic growth with and without the interaction term (see BGL2). The interaction term bears a positive sign, yet it is statistically insignificant. This implies that the effect of FDI is not necessarily conditional on a minimum threshold level of human capital for transition economies. Our results complement that of Borensztein et al. (1998): as most transition economies lie above the threshold level of human capital, the positive effect of FDI on growth is found independent of the level of human capital for this set of countries.

In the third column of Table 3 (BGL3), we add domestic investment. Domestic investment is defined as the ratio of gross domestic fixed investment to GDP. The accumulation of domestic capital is also found to be a determining factor for economic growth in transition economies. Nevertheless, the significance of other variables is unaffected after including investment. In particular, FDI remains statistically significant and robust. 
The fourth column (MRW) reports the specification by Mankiw, Romer and Weil (1992). With fewer explanatory variables, R-square declines. Yet the robustness of the FDI variable remains the same: after controlling for the initial level of income, human capital, domestic investment and population growth, FDI is still found to be a very important determinant of economic growth in transition.

The last column of Table 3 contains the specification proposed by Easterly (2001). In the model, the author attributes the slow rates of economic growth of developing countries in recent years to external shocks. Such shocks include the slowdown in the developed countries. Transition economies heavily trade with OECD countries because of geographical and historical proximity to the West. In the last column, we add the average of GDP growth in OECD countries as a proxy for global factors that may affect growth of transition economies. Number of telephone lines as a proxy for infrastructure quality is also added. Once again, FDI is found to have a positive effect on growth.

Although our results strongly support a positive impact of FDI on economic growth in various specifications, the coefficient of human capital is often negative and sometimes significant. One possible explanation of this finding is that the average number of completed years of schooling per worker in socialist economies was very high and, as transition progresses, declines. The reasons for this decline are numerous and one of them is diminishing public financial support. As a consequence, for most of this period, average years of education decline while growth rates do not. That would explain this inverse relation. Another explanation would be that the level of human capital at the outset of the transition is "artificially high" and as such human capital contributes less than expected to economic 
growth. ${ }^{9}$ This can happen for a number of reasons. For instance, Boeri (2000) stresses that excessive specialization of socialist educational systems is finally starting to show its effects in the lack of flexibility of the labor force. Gundlach (2001) argues that an important factor explaining the relative poor performance of former East Germany, vis-à-vis West Germany, is the poor quality of the human capital stock in the former. And Campos and Dabusinskas (2001) argue that additional frictions are generated during the transition by problems in the occupational structure: at the outset, there are too many rocket scientists and not enough marketing clerks.

\section{Sensitivity Analysis}

In the previous section, using different econometric specifications we showed that in transition economies the impact of FDI on growth is statistically significant and positive. How robust is this result? There are at least three important concerns in this respect: the simultaneity problem or reverse causality, the endogeneity of FDI, and the biases in our estimates due to omitted variables. In this section, we investigate each of these possibilities.

\subsection{Reverse causality}

In assessing the effect of FDI on economic growth, one important concern is the possibility of reverse causality, namely that fast growing countries may attract more FDI. If foreign investors believe that the host country's high growth rate is sustainable, this expectation

\footnotetext{
${ }^{9}$ We are thankful to an anonymous referee for this point.
} 
should serve as an additional reason to invest in that country. Here we test directly for reverse causality by conducting Granger-causality tests.

The Granger-causality framework has endured the test of time because of its elegance and strong intuitive appeal: the notion that an event in the future cannot cause one in the past. ${ }^{10}$ Consider two time series, $x_{t}$ and $y_{t}$. Series $x_{t}$ is said to Granger-cause series $y_{t}$ if, in a regression of $y_{t}$ on lagged $y$ 's and lagged $x$ 's, the coefficients of the lagged $x$ 's are jointly significantly different from zero.

There are two critical issues that have to be addressed in conducting Granger causality tests. The first concerns the length and frequency of the time lags. On their length, Granger admonishes that "using data measured over intervals much wider than actual causal lags can also destroy causal interpretation" (Granger, 1987, 49). We use one-year periods. As for their frequency, there are a number of tests to determine the "optimal number of lags," but because ours is a short panel we used a grid procedure to evaluate the robustness of the results presented below.

The second issue we must attend to arises from the inclusion on the right-hand side of the (lagged) dependent variable, referred to in the econometric literature as the dynamic panel problem: unless the time dimension of the panel is very large, parameter estimates will be inconsistent and biased. ${ }^{11}$ When there is a country-specific effect that is time invariant and unobservable, then the lagged dependent variable will be correlated with the error term and OLS will lead to asymptotically biased estimates. While the best solution to this problem is

\footnotetext{
${ }^{10}$ Granger remarks that "causation is a non-symmetric relationship, and there are various ways in which asymmetry can be introduced, the most important of which are controllability, a relevant theory, outside knowledge, and temporal priority" $(1987,49$.

${ }^{11}$ See, e.g., Baltagi (1995).
} 
still an object of debate in the econometrics literature, ${ }^{12}$ in one of the few studies focusing on "short and wide" panels (like ours), Kiviet finds that the instrumental variable approach pioneered by Anderson and Hsiao (1982) performs as well as any other alternative.

Table 4 presents these Granger causality results using the Anderson-Hsiao estimator. The results show that lagged FDI is a weak predictor of current FDI levels and that lagged per capita FDI is a bad predictor of current levels of per capita FDI. The statistical insignificance of lagged per capita growth in the second and fourth columns imply that growth does not Granger-cause FDI or per capita FDI in transition economies between 1990 and 1998. This is a very important result because it weakens concerns that may arise from the possibility that fast growing countries attract more FDI. This does not seem to be the case during the transition.

\subsection{Endogeneity}

As noted, the determinants of FDI vary a great deal across transition. For instance, the abundance of natural resources might be an important factor for FDI going into Russia, while this may not be an important factor in the Vysegrad countries. One would expect that FDI flows to transition economies will concentrate in different sectors, with consequences in terms of the type and extent of technology transferred and, ultimately, with differential impacts on aggregate growth. Given that sectoral data on FDI in transition is not available, one way to evaluate this concern is to instrument FDI in an attempt to account for these differences. We thus proceed by re-estimating the specifications in Table 3 using as instruments for FDI: the lagged stock of FDI (as a proxy for agglomeration effects), the quality of the bureaucracy, the

\footnotetext{
${ }^{12}$ See Kiviet (1995) and Judson and Owen (1999).
} 
number of telephone lines (as a proxy for the quality of infrastructure), the external liberalisation index, and OECD growth. ${ }^{13}$

Overall, the signs of most coefficients from fixed effects IV models in Table 5 are the same as in Table 3. The magnitude of two key variables, FDI and human capital, becomes somewhat greater when we estimate with instrumental variables. Yet, the positive and significant effect of FDI on growth rate is unchanged.

Columns BGL1 and BGL2 show that the positive and statistically significant effect of FDI on real GDP growth obtain with or without the inclusion of the interaction term between FDI and human capital. The negative sign on the initial income coefficient supports the prediction of convergence from the neoclassical model. It can also be seen that stabilisation policies (as proxied by the inflation rate) have played a role in generating faster rates of economic growth. We also find that political stability (as proxied by dummy variable for armed conflict) has also contributed to higher growth rates during the transition period.

In column 3 (BGL3), the inclusion of domestic investment does not affect the positive impact of FDI on growth. As it can be seen, the coefficient of FDI in BGL3 is very similar to that in BGL1 and domestic investment alone has a positive coefficient. This implies that a positive effect of FDI is independent of the presence of domestic investment and that FDI is complementary to domestic investment in increasing the growth rate.

The same pattern is detected in MRW. FDI remains an important determinant for faster economic growth and the size of the FDI coefficient is more pronounced in IV

\footnotetext{
${ }^{13}$ The results do not change after a dummy for the countries of the Commonwealth of Independent States is introduced. In particular, the coefficient on FDI remains positive and significant at the 1 percent level. These results are available from the authors upon request.
} 
estimation. The remaining explanatory variables are the same as before. Low initial income level and high investment rate lead to higher rates of economic growth.

The last column of Table 5 shows the specification proposed by Easterly (2001). Again, the coefficient on FDI is positive and statistically significant at the 1 percent level. The results also show that the effects on the growth rates of transition economies of their initial income levels, inflation rates and of the level of economic activity in the OECD countries are all statistically significant and carry their expected signs. We find that the quality of the infrastructure does not seem to be an important determinant of growth rates in the transition economies. $^{14}$

In summary, we found that in the context of the transition economies FDI have a positive impact on the annual rates of economic growth. This finding is robust after we instrument FDI in order to account for the variety of determinants in different transition economies. Irrespective of whether FDI is attracted by good policies or favourable initial conditions, the positive effect on growth rates seems to hold.

\subsection{Omitted Variables}

There are at least two reasons for being attentive to the possibility of biases generated by omitted variables. One is that we are using reduced forms from global cross-country studies applied to the transition context. We believe these models are appropriate for this exercise because they guarantee a level of comparability: we need to argue that the effect of FDI on growth in transition obtains using standard specifications from the literature. On the other

\footnotetext{
${ }^{14}$ It should be mentioned that this latter result might be due to the poor quality of the data and the lack of alternative measures of infrastructure quality in these countries. We found data on another proxy for the quality of infrastructure, the percentage of roads paved, but quality was very poor.
} 
hand, we recognize that the specificities of the transition experience introduce potential omitted variable biases beyond our fixed effects. Introducing a wider range of explanatory variables that try to capture the various aspects of economic reform is one way to deal with this issue.

Another reason is related to some potential deficiencies of the Granger causality evidence discussed above. One can argue that FDI and growth are jointly determined by variables such as macroeconomic reforms and stabilization in the host country. If FDI is faster than growth rates to respond to these reforms, then the Granger evidence will show that FDI precedes growth even if the true determinants of growth are not FDI but reform variables (Gastanaga et al., 1998). Although our discussion of the data in Section 2 does not support the view that FDI has reacted earlier than growth rates in the transition period, the enormous difficulties in measuring economic reform calls for a closer look at this possibility.

Table 6 summarizes our attempts to deal with the effects of omitted variables bias. We re-estimate the five specifications from Table 5 adding a wider range of reform variables, namely an index of external liberalization, openness to international trade and a measure of the terms of trade. Notice that there are in addition to variables capturing stabilization efforts (inflation rate), changes in fiscal policy stance (government consumption) and institutional reform (the quality of the bureaucracy).

The overall pattern of results remains. First, the coefficient on FDI is positive and statistically significant at the 1 percent level throughout. This again holds regardless of the presence of the interaction term between human capital and FDI (see BGL2). ${ }^{15}$ The coefficients on initial income, domestic investment, dummy for armed conflict (as a proxy for

${ }^{15}$ These results also obtain if we add one additional reform indicator at a time. These are not reported for the sake of space. 
political instability) and the index of external liberalization all carry the expected signs and are statistically significant.

\section{Conclusions}

The objective of this paper was to evaluate empirically the impact of FDI on the rates of economic growth of host countries. The basic motivation for this study is that the empirical literature has had difficulties in establishing the result predicted by economic theory, namely that the effect of FDI on host country growth is positive and statistically significant. One reason for these difficulties is that theory equates FDI to technology transferred, while in most countries and regions of the world FDI encompasses an array of arrangements that goes well beyond pure technology transfer. We conjecture that transition economies may be the right context for addressing this problem because of the unique combination of a complete industrial structure and a sizeable technological gap. On the other hand, there are important costs in studying the transition economies. In particular, the transition period has been relatively short and marked by substantial structural change. As a consequence, the application of the aggregate production function approach has to be accompanied by a discussion of potential biases generated by the peculiarities of the transition experience itself.

Our main result is that the effect of FDI on economic growth in transition economies is positive and statistically significant. This result obtains using standard specifications from the literature and irrespective of the presence of the interaction term between FDI and human capital. Recall that the presence of the latter is the condition usually pointed out as necessary to generate the positive impact of FDI on host countries' growth rates. In addition, our results 
for transition economies seem robust after correcting for reverse causality, endogeneity and omitted variable bias.

Our results show that FDI is a crucially important explanatory variable for growth in transition economies, an issue that has been largely ignored by the empirical literature.

The policy implications from our results should not be overlooked. So far, transition economies have by and large been shy in their attempts to attract FDI and we believe our results invite re-thinking the prevalent attitude.

The paper can not solve the difficulties in distinguishing empirically between old and new theories of economic growth. In other words, it is beyond the scope of this paper to impose whether the impact of FDI on growth is to be interpreted as a long-run (an endogenous growth interpretation) or as a short-run effect (a standard neoclassical interpretation). The results suggest, however, that the transition economies are an appropriate setting as the effect we find is positive, statistically significant and robust.

One suggestion for future research is that there are important potential improvements in terms of measurement that should be pursued. For instance, better measurements for geographical distances (for example taking into account travel time and bureaucratic delays) and the abundance of natural resources would certainly contribute to more precise estimates of the effects of FDI. In this respect, few dimensions promise more benefits than a better grasp of human capital. 


\section{References}

Aghion, P. and Howitt, P. (1998). Endogenous Growth Theory, Cambridge, MIT Press.

Anderson, T. and Hsiao, C. (1982). "Formulation and Estimation of Dynamic Models using Panel Data," Journal of Econometrics, Vol. 18, pp. 47-82.

Baltagi, B. (1995). Econometric Analysis of Panel Data (John Wiley \& Sons, New York).

Barro, R., and Sala-i-Martin, X. (1995). Economic Growth. New York: McGraw Hill.

Berg, A., Borensztein, E., Sahay, R. and Zettelmeyer, J. (1999). "The Evolution of Output in Transition Economies: Explaining the Difference", IMF Working Paper WP/99/73.

Bevan, A. and Estrin, S. (2000). "The Determinants of Foreign Direct Investment in Transition Economies," Ann Arbor, William Davidson Institute Working Paper No. 342.

Blomstrom, M. (1992). "Host Country Benefits of Foreign Investment," NBER Working Paper No. W3615, March.

Blomstrom, M., Lipsey, R. and Zejan, M. (1994). "What Explains the Growth of Developing Countries?" in Baumol, W., Nelson, R. and E. Wolff (eds) Convergence of Productivity, Oxford, Oxford University Press.

Borensztein, E., De Gregorio, J. and Lee, J. (1998). "How Does Foreign Direct Investment Affect Economic Growth?” Journal of International Economics Vol. 45, pp. 115-135.

Boeri, T. (2000). Structural Change, Welfare Systems, and Labour Reallocation: Lessons from the Transition of Formerly Planned Economies, Oxford: Oxford University Press.

Brems, H. (1970). "A Growth Model of International Direct Investment," American Economic Review Vol. 60, pp. 320-331.

Campos, N. and Coricelli, F. (forthcoming). "Growth in Transition: What We Know, What We Don't and What We Should," Journal of Economic Literature.

Campos, N. and Dabusinskas, A. (2001). "So Many Rocket Scientists, So Few Marketing Clerks: Determinants of Occupational Change during the Estonian Transition," Prague, CERGE-EI Discussion Paper No. 59.

Durlauf, S. and Quah, D. (1999). "The New Empirics of Economic Growth.” In J. Taylor and M. Woodford, Eds., Handbook of Macroeconomics, Vol. 1A. Amsterdam, Elsevier.

Easterly, W. (2001). “The Lost Decades: Developing Countries' Stagnation in Spite of Policy Reform 1980-1998," Journal of Economic Growth Vol. 6, pp. 135-157. 
Gastanaga, V., Nugent, J. and Pashamova, B. (1998). "Host Country Reforms and FDI Inflows: How Much Difference do they Make?” World Development Vol. 26, pp. 1299-1314.

Granger, C.W., (1987). "Causal Inference," in The New Palgrave: Econometrics, New York, W.W. Norton.

Gundlach, E. (2001). "Growth Effects of EU Membership: The Case of East Germany," Laxenburg, IIASA, IR-01-035.

Hanson, G. (2001). “Should Countries Promote Foreign Direct Investment?” Geneva, G-24 Discussion Paper Series No. 9.

Johnson, S., Kaufmann, D. and Shleifer, A. (1997). "The Unofficial Economy in Transition," Brookings Papers on Economic Activity No. 2, pp. 159-221.

Judson, R. and Owen, A. (1999). "Estimating Dynamic Panel Data Models: A Guide for Macroeconomists," Economic Letters Vol. 65, pp. 9-15.

Kinoshita, Y. and Campos, N. (2001). "Agglomeration and the locational determinants of FDI in transition economies," CUNY and University of Newcastle, mimeo.

Kiviet, J. (1995). "On Bias, Inconsistency, and Efficiency of Various Estimators in Dynamic Panel Data Models," Journal of Econometrics Vol. 68, pp. 53-78.

Lankes, H., and A. Venables (1996) "Foreign direct investment in economic transition: The changing pattern of investments," Economics of Transition Vol.4, pp. 331-347.

Lensink, R. and Morrissey, O. (2001). "Foreign Direct Investment: Flows, Volatility and Growth in Developing Countries," University of Nottingham, mimeo.

Lipsey, R. (2000). “Interpreting Developed Countries' Foreign Direct Investment," NBER Working Paper No. 7810, July.

Mankiw, G., Romer, D. and Weil, D. (1992). "A Contribution to the Empirics of Economic Growth”, Quarterly Journal of Economics, 107 (2), pp. 407-437, May.

de Mello, L. (1997). "Foreign Direct Investment in Developing Countries and Growth: A Selective Survey,” Journal of Development Studies Vol. 34, pp. 1-34.

de Mello, L. (1999). "Foreign Direct Investment-Led Growth: Evidence from Time Series and Panel Data," Oxford Economic Papers Vol. 51, pp. 133-151.

Meyer, K. and Pind, C. (1999). "The Slow Growth of Foreign Direct Investment in the Soviet Union Successor States,” Economics of Transition Vol. 7, pp. 201-214. 
William Davidson Institute Working Paper 438

Saltz, I. (1992). "The Negative Correlation between Foreign Direct Investment and Economic Growth in the Third World: Theory and Evidence," Rivista Internazionale di Scienze Economiche e Commerciali Vol. 39, pp. 617-633, July.

Temple, J. (1999). “The New Growth Evidence.” Journal of Economic Literature Vol. 37, pp. 112-156. 
Figure 1. Real GDP index (1989=100)

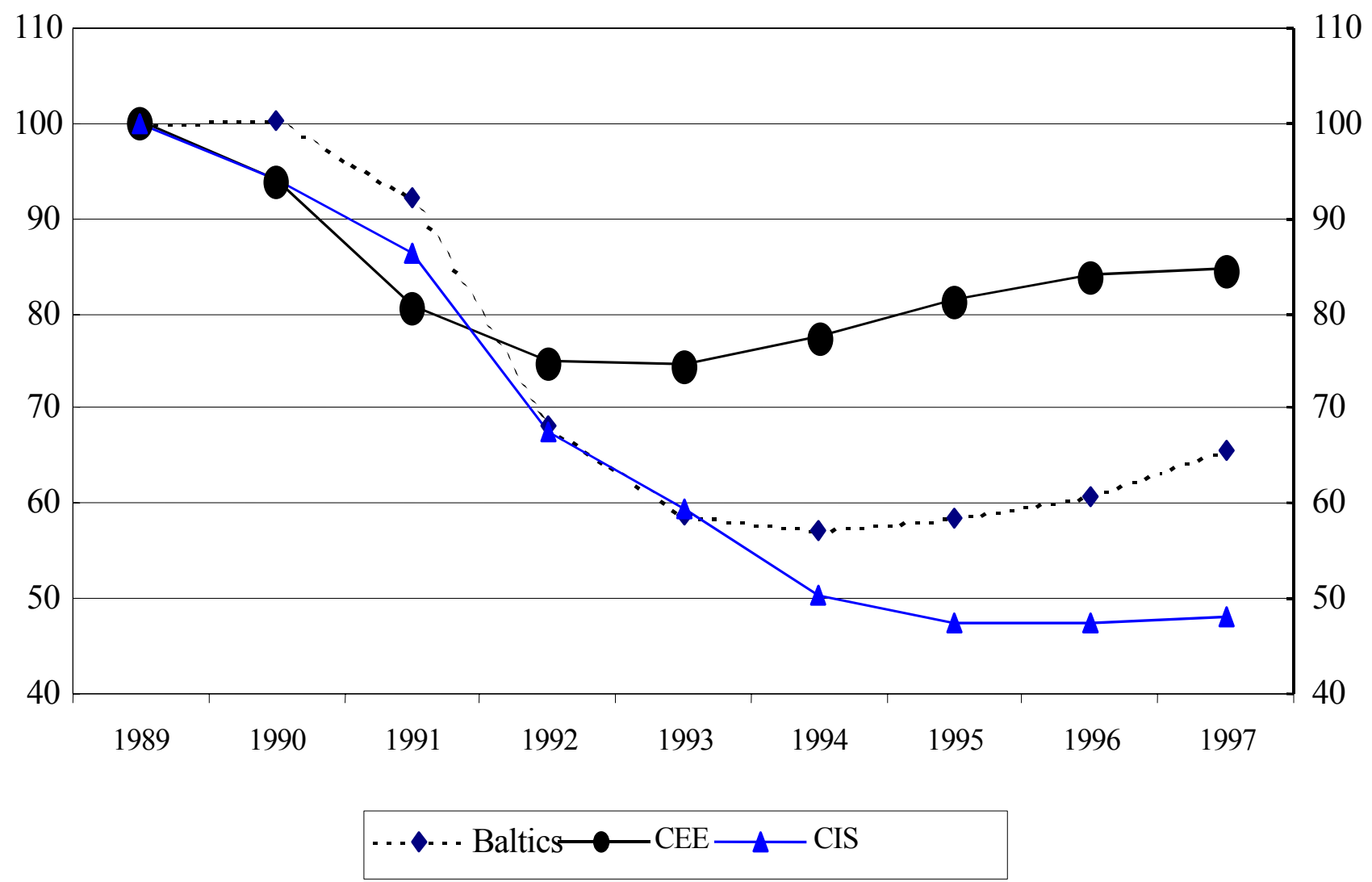




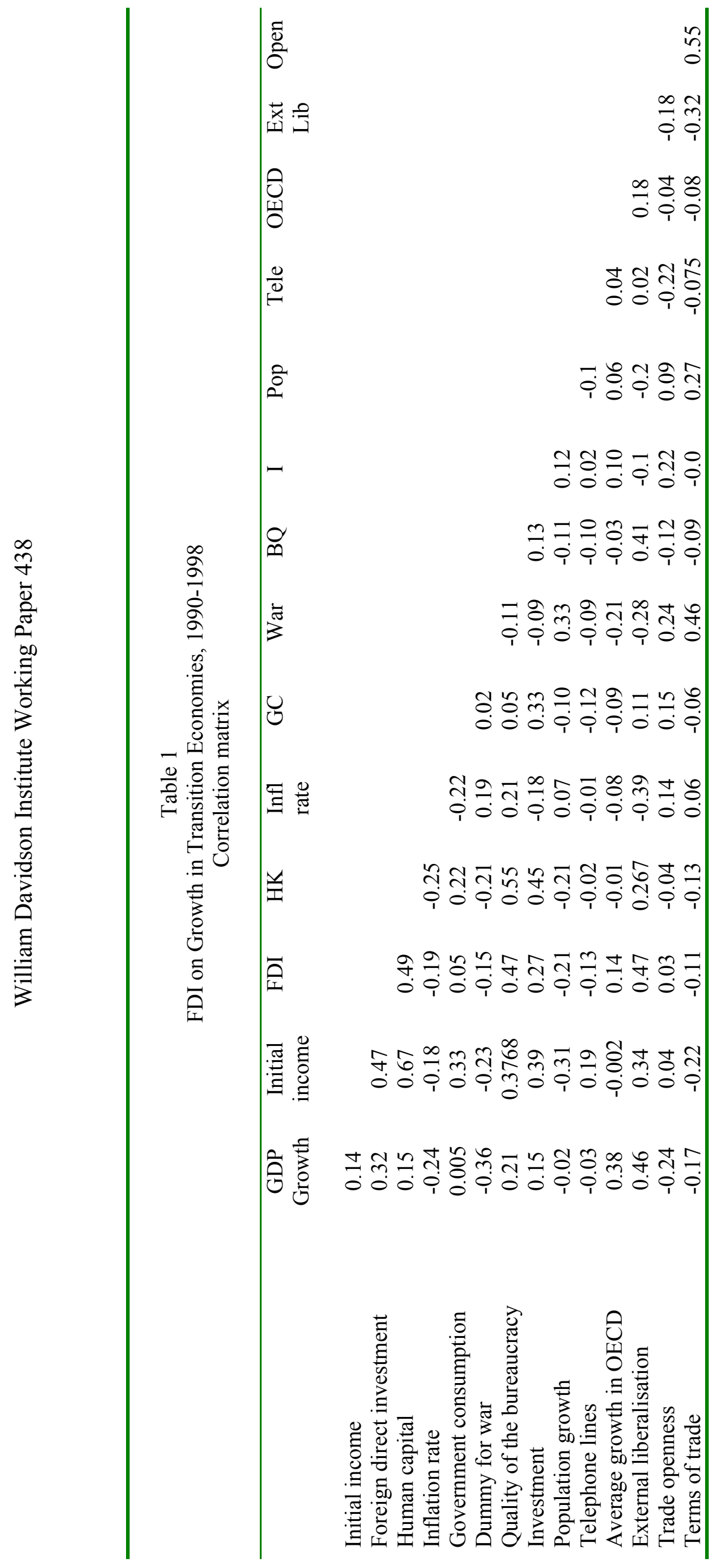


William Davidson Institute Working Paper 438

Table 2.

Foreign Direct Investment in Transition Economies

Cumulative FDI Cumulative FDI Cumulative FDI Average FDI inflow as \% inflows, 1988-99 inflows as \% of inflows per capita, of gross domestic (Billion dollars) GDP, 1988-99 1988-99 (dollars) investment, 1997-99

$\begin{array}{lcccc}\text { BALTIC } & 2.10 & 30.27 & 923.67 & 27.00 \\ \text { BALKANS } & 2.07 & 16.85 & 277.50 & 21.40 \\ \text { VISEGRAD } & 14.41 & 22.30 & 1122.80 & 13.40 \\ \text { ASIA } & 1.73 & 32.35 & 183.00 & 39.28 \\ \text { BUR } & 8.17 & 9.37 & 91.00 & 7.33 \\ & & & & \\ \text { CEEC } & 6.19 & 23.14 & 774.66 & 20.60 \\ \text { CIS } & 4.95 & 20.85 & 137.00 & 23.31\end{array}$

Source: Campos and Coricelli (forthcoming). 
Table 3

The Impact of FDI on Growth in Transition Economies, 1990-1998 Fixed-Effects Panel Data Estimates

\begin{tabular}{|c|c|c|c|c|c|}
\hline & BGL1 & BGL2 & BGL3 & MRW & EAST \\
\hline Constant & $\begin{array}{l}72.24 * * \\
(33.01)\end{array}$ & $\begin{array}{l}72.88 * * \\
(33.02)\end{array}$ & $\begin{array}{l}116.22 * * * \\
(35.42)\end{array}$ & $\begin{array}{l}200.13 * * * \\
(36.08)\end{array}$ & $\begin{array}{l}125.02 * * * \\
(28.86)\end{array}$ \\
\hline Initial income & $\begin{array}{c}-6.399 * * * \\
(1.98)\end{array}$ & $\begin{array}{c}-6.91 * * * \\
(2.031)\end{array}$ & $\begin{array}{c}-7.89 * * * \\
(1.98)\end{array}$ & $\begin{array}{c}-10.92 * * * \\
(2.17)\end{array}$ & $\begin{array}{c}-8.20 * * * \\
(2.067)\end{array}$ \\
\hline Human capital & $\begin{array}{l}-.501 \\
(.321\end{array}$ & $\begin{array}{l}-.4756 \\
(.322)\end{array}$ & $\begin{array}{c}-.932 * * * \\
(.344)\end{array}$ & $\begin{array}{l}-1.54 * * * \\
(.37)\end{array}$ & $\begin{array}{c}-.88 * * * \\
(.301)\end{array}$ \\
\hline Foreign direct investment & $\begin{array}{c}.449 * * * \\
(.144)\end{array}$ & $\begin{array}{l}.352 * * \\
(.173)\end{array}$ & $\begin{array}{c}.444 * * * \\
(.141)\end{array}$ & $\begin{array}{c}.743 * * * \\
(.141)\end{array}$ & $\begin{array}{c}.561 * * * \\
(.143)\end{array}$ \\
\hline Interaction term $(\mathrm{FDI} * \mathrm{HK})$ & & $\begin{array}{c}.001 \\
(.001)\end{array}$ & & & \\
\hline Inflation rate & $\begin{array}{l}-.001 * * \\
(.0005)\end{array}$ & $\begin{array}{c}-.0009 * * \\
(.0004)\end{array}$ & $\begin{array}{l}-.0009 * \\
(.0004)\end{array}$ & & $\begin{array}{l}-.001 * \\
(.0005)\end{array}$ \\
\hline Government consumption & $\begin{array}{c}.335 \\
(.242)\end{array}$ & $\begin{array}{c}.401 \\
(.251)\end{array}$ & $\begin{array}{c}.222 \\
(.241)\end{array}$ & & \\
\hline Dummy for war & $\begin{array}{l}-21.86^{* * *} \\
(3.79)\end{array}$ & $\begin{array}{l}-22.21 * * * \\
(3.81)\end{array}$ & $\begin{array}{l}-19.94 * * * \\
(3.765)\end{array}$ & & \\
\hline Quality of the bureaucracy & $\begin{array}{c}4.06^{* * *} \\
(1.47)\end{array}$ & $\begin{array}{l}3.91 * * * \\
(1.48)\end{array}$ & $\begin{array}{l}3.55^{* *} \\
(1.45)\end{array}$ & & \\
\hline Investment & & & $\begin{array}{l}.482 * * * \\
(.159)\end{array}$ & $\begin{array}{l}.705 * * * \\
(.177)\end{array}$ & \\
\hline Population growth & & & & $\begin{array}{l}-.364 \\
(1.31)\end{array}$ & \\
\hline Telephone lines & & & & & $\begin{array}{l}.0001 \\
(.001)\end{array}$ \\
\hline $\begin{array}{l}\text { GDP Growth in OECD } \\
\text { countries (average) }\end{array}$ & & & & & $\begin{array}{c}4.11 * * * \\
(.839)\end{array}$ \\
\hline $\begin{array}{l}\text { No. observations } \\
\text { R-squared }\end{array}$ & $\begin{array}{c}174 \\
0.445\end{array}$ & $\begin{array}{c}174 \\
0.448\end{array}$ & $\begin{array}{c}173 \\
0.476\end{array}$ & $\begin{array}{c}173 \\
0.319\end{array}$ & $\begin{array}{c}182 \\
0.387\end{array}$ \\
\hline \multicolumn{6}{|c|}{$\begin{array}{l}\text { Notes: Dependent variable is real GDP growth, standard errors in par } \\
\text { countries and years are not reported. Specifications are as follows: B } \\
\text { Borensztein, de Gregorio and Lee (1998), MRW is from Mankiw, Ro } \\
\text { EAST is from Easterly (2001). } \\
* \text { denotes statistically significant at the } 10 \text { percent level, } \\
\text { ** denotes statistically significant at the } 5 \text { percent level, and } \\
* * * \text { denotes statistically significant at the } 1 \text { percent level. }\end{array}$} \\
\hline
\end{tabular}


William Davidson Institute Working Paper 438

Table 4.

Granger Causality Evidence for Transition Economies, 1990-1998

Do Fast Growing Economies Attract More FDI?

\begin{tabular}{|c|c|c|c|c|}
\hline & \multicolumn{4}{|c|}{ Dependent variable } \\
\hline & FDI & FDI & $\begin{array}{l}\text { FDI per } \\
\text { capita }\end{array}$ & $\begin{array}{l}\text { FDI per } \\
\text { capita }\end{array}$ \\
\hline Lagged FDI & $\begin{array}{l}.914^{*} \\
(.553)\end{array}$ & $\begin{array}{l}.725 \\
(.489)\end{array}$ & & \\
\hline Lagged FDI per capita & & & $\begin{array}{c}.229 \\
(.299)\end{array}$ & $\begin{array}{l}.135 \\
(.284)\end{array}$ \\
\hline $\begin{array}{l}\text { Lagged real per capita } \\
\text { growth }\end{array}$ & & $\begin{array}{c}3.74 \\
(7.14)\end{array}$ & & $\begin{array}{l}.299 \\
(.495)\end{array}$ \\
\hline Adjusted R-squared & .187 & .192 & .186 & .161 \\
\hline No. observations & 144 & 138 & 144 & 138 \\
\hline \multicolumn{5}{|c|}{$\begin{array}{l}\text { Note: Anderson-Hsiao IV estimates are reported with standard errors in parenthesis. } \\
* \text { denotes statistically significant at the } 10 \text { percent level, } \\
* * \text { denotes statistically significant at the } 5 \text { percent level, and } \\
* * * \text { denotes statistically significant at the } 1 \text { percent level. }\end{array}$} \\
\hline
\end{tabular}


Table 5

The Impact of FDI on Growth in Transition Economies, 1990-1998

Fixed-Effects Panel Data Instrumental Variables Estimates

\begin{tabular}{|c|c|c|c|c|c|}
\hline & BGL1 & BGL2 & BGL3 & MRW & EAST \\
\hline Constant & $\begin{array}{c}142.42 * * * \\
(54.62)\end{array}$ & $\begin{array}{c}80.96 * * \\
(41.35)\end{array}$ & $\begin{array}{c}171.74 * * * \\
(55.11)\end{array}$ & $\begin{array}{c}234.51 * * * \\
\quad(52.19)\end{array}$ & $\begin{array}{c}177.03 * * * \\
(44.21)\end{array}$ \\
\hline Initial income & $\begin{array}{c}-8.75 * * * \\
(2.82)\end{array}$ & $\begin{array}{c}-5.66^{* *} \\
(2.22)\end{array}$ & $\begin{array}{c}-10.27 * * * \\
(2.85)\end{array}$ & $\begin{array}{c}-12.25 * * * \\
(2.98)\end{array}$ & $\begin{array}{c}-9.45 * * * \\
(2.69)\end{array}$ \\
\hline Human capital & $\begin{array}{c}-.996 * * \\
(.484)\end{array}$ & $\begin{array}{l}-.594 \\
(.392)\end{array}$ & $\begin{array}{c}-1.27 * * * \\
(.491)\end{array}$ & $\begin{array}{c}-1.83 * * * \\
(.49)\end{array}$ & $\begin{array}{c}-1.34 * * * \\
(.42)\end{array}$ \\
\hline Foreign direct investment & $\begin{array}{l}1.53 * * * \\
(.4059)\end{array}$ & $\begin{array}{l}.862 * * * \\
(.302)\end{array}$ & $\begin{array}{c}1.52 * * * \\
(.399)\end{array}$ & $\begin{array}{c}1.79 * * * \\
(.318)\end{array}$ & $\begin{array}{c}1.561 * * * \\
(.342)\end{array}$ \\
\hline Interaction term $(\mathrm{FDI} * \mathrm{HK})$ & & $\begin{array}{r}-.0001 \\
(.001)\end{array}$ & & & \\
\hline Inflation rate & $\begin{array}{l}-.0009 \\
(.0006)\end{array}$ & $\begin{array}{c}-.0009 * * \\
(.0005)\end{array}$ & $\begin{array}{l}-.0008 \\
(.0005)\end{array}$ & & $\begin{array}{c}-.0009 * * \\
(.0005)\end{array}$ \\
\hline Government consumption & $\begin{array}{l}.117 \\
(.331)\end{array}$ & $\begin{array}{l}.0009 \\
(.2939)\end{array}$ & $\begin{array}{l}.067 \\
(.328)\end{array}$ & & \\
\hline Dummy for war & $\begin{array}{c}-19.17 * * * \\
(6.265)\end{array}$ & $\begin{array}{c}-21.31 * * * \\
(5.38)\end{array}$ & $\begin{array}{c}-18.62 * * * \\
(6.208)\end{array}$ & & \\
\hline Quality of the bureaucracy & $\begin{array}{c}.501 \\
(2.53)\end{array}$ & $\begin{array}{l}3.61^{*} \\
(1.86)\end{array}$ & $\begin{array}{c}-.143 \\
(2.505)\end{array}$ & & \\
\hline Investment & & & $\begin{array}{l}.511 * * \\
(.225)\end{array}$ & $\begin{array}{l}.552 * * \\
(.253)\end{array}$ & \\
\hline Population growth & & & & $\begin{array}{l}-.052 \\
(1.61)\end{array}$ & \\
\hline Telephone lines & & & & & $\begin{array}{l}.0001 \\
(.001)\end{array}$ \\
\hline Average growth in OECD & & & & & $\begin{array}{c}2.72 * * * \\
(1.04)\end{array}$ \\
\hline $\begin{array}{l}\text { No. observations } \\
\text { R-squared }\end{array}$ & $\begin{array}{c}157 \\
0.069\end{array}$ & $\begin{array}{c}157 \\
0.331\end{array}$ & $\begin{array}{c}156 \\
0.104\end{array}$ & $\begin{array}{c}156 \\
0.124\end{array}$ & $\begin{array}{c}164 \\
0.042\end{array}$ \\
\hline \multicolumn{6}{|c|}{$\begin{array}{l}\text { Notes: Dependent variable is real GDP growth, standard errors in pa } \\
\text { countries and years are not reported. Specifications are as follows: B } \\
\text { Borensztein, de Gregorio and Lee (1998), MRW is from Mankiw, R } \\
\text { EAST is from Easterly (2001). Instruments for FDI are: lagged stoc } \\
\text { bureaucracy, telephone lines, external liberalisation index, and OEC } \\
* \text { denotes statistically significant at the } 10 \text { percent level, } \\
\text { ** denotes statistically significant at the } 5 \text { percent level, and } \\
* * * \text { denotes statistically significant at the } 1 \text { percent level. }\end{array}$} \\
\hline
\end{tabular}




\section{Table 6}

The Impact of FDI on Growth in Transition Economies, 1990-1998

Fixed-Effects Panel Data Instrumental Variables Estimates (with Additional Reform Indicators)

\begin{tabular}{|c|c|c|c|c|c|}
\hline & BGL1 & BGL2 & BGL3 & MRW & EAST \\
\hline Constant & $\begin{array}{l}153.43 * * * \\
(59.19)\end{array}$ & $\begin{array}{l}91.41 * * \\
(43.33)\end{array}$ & $\begin{array}{c}165.75 * * * \\
(58.45)\end{array}$ & $\begin{array}{c}176.27 * * * \\
(54.85)\end{array}$ & $\begin{array}{c}153.07 * * * \\
(54.05)\end{array}$ \\
\hline Initial income & $\begin{array}{c}-7.62 * * \\
(3.16)\end{array}$ & $\begin{array}{l}-4.83^{*} \\
(2.69)\end{array}$ & $\begin{array}{c}-8.83 * * * \\
(3.187)\end{array}$ & $\begin{array}{c}-8.759 * * * \\
(3.17)\end{array}$ & $\begin{array}{l}-7.26 * * \\
(3.089)\end{array}$ \\
\hline Human capital & $\begin{array}{c}-1.05 * * \\
(.528)\end{array}$ & $\begin{array}{l}-.617 \\
(.403)\end{array}$ & $\begin{array}{c}-1.198 * * \\
(.529)\end{array}$ & $\begin{array}{c}-1.519 * * * \\
(.496)\end{array}$ & $\begin{array}{c}-1.24 * * * \\
(.45)\end{array}$ \\
\hline Foreign direct investment & $\begin{array}{c}1.609 * * * \\
(.486)\end{array}$ & $\begin{array}{l}.88 * * * \\
(.312)\end{array}$ & $\begin{array}{l}1.589 * * * \\
(.477)\end{array}$ & $\begin{array}{c}1.54 * * * \\
(.372)\end{array}$ & $\begin{array}{c}1.43 * * * \\
(.39)\end{array}$ \\
\hline Interaction term $(\mathrm{FDI} * \mathrm{HK})$ & & $\begin{array}{l}-.0001 \\
(.0001)\end{array}$ & & & \\
\hline Inflation rate & $\begin{array}{l}-.0003 \\
(.0007)\end{array}$ & $\begin{array}{l}-.0002 \\
(.0005)\end{array}$ & $\begin{array}{l}-.0003 \\
(.0007)\end{array}$ & & $\begin{array}{l}-.0001 \\
(.0006)\end{array}$ \\
\hline Government consumption & $\begin{array}{l}-.1265 \\
(.399)\end{array}$ & $\begin{array}{l}-.318 \\
(.347)\end{array}$ & $\begin{array}{l}-.133 \\
(.397)\end{array}$ & & \\
\hline Dummy for war & $\begin{array}{l}-22.09 * * \\
(9.254)\end{array}$ & $\begin{array}{c}-21.79 * * * \\
(8.001)\end{array}$ & $\begin{array}{c}-21.02 * * \\
(9.22)\end{array}$ & & \\
\hline Quality of the bureaucracy & $\begin{array}{l}-1.07 \\
(2.88)\end{array}$ & $\begin{array}{c}1.89 \\
(2.102)\end{array}$ & $\begin{array}{l}-1.77 \\
(2.85)\end{array}$ & & \\
\hline Investment & & & $\begin{array}{l}.431 * \\
(.251)\end{array}$ & $\begin{array}{l}.488 * \\
(.253)\end{array}$ & \\
\hline Population growth & & & & $\begin{array}{l}-.503 \\
(1.58)\end{array}$ & \\
\hline Telephone lines & & & & & $\begin{array}{l}.0001 \\
(.001)\end{array}$ \\
\hline Average growth in OECD & & & & & $\begin{array}{l}2.04 * \\
(1.13)\end{array}$ \\
\hline $\begin{array}{l}\text { External liberalisation } \\
\text { index }\end{array}$ & $\begin{array}{c}9.19 \\
(6.67)\end{array}$ & $\begin{array}{l}13.87 * * \\
(5.768)\end{array}$ & $\begin{array}{c}9.533 \\
(6.663)\end{array}$ & $\begin{array}{l}13.058^{* *} \\
(5.74)\end{array}$ & $\begin{array}{c}12.48 * * \\
(6.27)\end{array}$ \\
\hline Trade openness & $\begin{array}{l}-.082 \\
(.093)\end{array}$ & $\begin{array}{l}-.109 \\
(.079)\end{array}$ & $\begin{array}{l}-.0581 \\
(.109)\end{array}$ & $\begin{array}{l}-.1369 \\
(.0974)\end{array}$ & $\begin{array}{l}-.116 \\
(.074)\end{array}$ \\
\hline Terms of trade & $\begin{array}{l}-4.69 \\
(3.57)\end{array}$ & $\begin{array}{l}-4.74 \\
(2.95)\end{array}$ & $\begin{array}{l}-4.833 \\
(4.716)\end{array}$ & $\begin{array}{c}1.073 \\
(3.942)\end{array}$ & $\begin{array}{l}-.753 \\
(2.41)\end{array}$ \\
\hline $\begin{array}{l}\text { No. observations } \\
\text { R-squared }\end{array}$ & $\begin{array}{c}146 \\
0.061\end{array}$ & $\begin{array}{c}146 \\
0.374\end{array}$ & $\begin{array}{c}145 \\
0.092\end{array}$ & $\begin{array}{c}145 \\
0.058\end{array}$ & $\begin{array}{c}153 \\
0.132\end{array}$ \\
\hline \multicolumn{6}{|c|}{$\begin{array}{l}\text { Notes: Dependent variable is real GDP growth, standard errors in } p \\
\text { countries and years are not reported. Specifications are as follows: } \\
\text { Borensztein, de Gregorio and Lee (1998), MRW is from Mankiw, } \\
\text { EAST is from Easterly (2001). Instruments for FDI are: lagged sto } \\
\text { bureaucracy, telephone lines, external liberalisation index, and OE } \\
* \text { denotes statistically significant at the } 10 \text { percent level, } \\
\text { ** denotes statistically significant at the } 5 \text { percent level, and } \\
* * * \text { denotes statistically significant at the } 1 \text { percent level. }\end{array}$} \\
\hline
\end{tabular}


William Davidson Institute Working Paper 438 


\section{DAVIDSON INSTITUTE WORKING PAPER SERIES - Most Recent Papers}

The entire Working Paper Series may be downloaded free of charge at: www.wdi.bus.umich.edu

CURRENT AS OF 3/12/02

\begin{tabular}{|c|c|c|}
\hline Publication & Authors & Date \\
\hline $\begin{array}{l}\text { No. 438: Foreign Direct Investment as Technology Transferred: } \\
\text { Some Panel Evidence from the Transition Economies }\end{array}$ & $\begin{array}{l}\text { Nauro F. Campos and Yuko } \\
\text { Kinoshita }\end{array}$ & Jan. 2002 \\
\hline No. 437: Whistleblowing, MNC's and Peace & Terry Morehead Dworkin & Feb. 2002 \\
\hline $\begin{array}{l}\text { No. 436: A Note on Measuring the Unofficial Economy in the Former } \\
\text { Soviet Republics }\end{array}$ & $\begin{array}{l}\text { Michael Alexeev and William } \\
\text { Pyle }\end{array}$ & Sept. 2001 \\
\hline $\begin{array}{l}\text { No. 435: The Ownership School vs. the Management School of State } \\
\text { Enterprise Reform: Evidence from China }\end{array}$ & David D. Li and Changqi Wu & Jan. 2002 \\
\hline $\begin{array}{l}\text { No. } 434 \text { Forthcoming in: The Journal of Economic Perspectives, "The } \\
\text { Effect of Ownership and Competitive Pressure on Firm Performance in } \\
\text { Transition Countries: Micro Evidence from Bulgaria, Romania and } \\
\text { Poland," } 16(2) \text { Feb. } 2002 .\end{array}$ & $\begin{array}{l}\text { Manuela Angelucci, Saul Estrin, } \\
\text { Jozef Konings, Zbigniew } \\
\text { Zolkiewski }\end{array}$ & Jan. 2002 \\
\hline No. 433: The End of Moderate Inflation in Three Transition Economies? & Josef C. Brada and Ali M. Kutan & Jan. 2002 \\
\hline $\begin{array}{l}\text { No. 432: What Drives the Speed of Job Reallocation During Episodes of } \\
\text { Massive Adjustment? }\end{array}$ & $\begin{array}{l}\text { Stepan Jurajda and Katherine } \\
\text { Terrell }\end{array}$ & Jan. 2002 \\
\hline No. 431: Competition and Corporate Governance in Transition & Saul Estrin & Dec. 2001 \\
\hline $\begin{array}{l}\text { No. 430: Corporate Governance in the Cause of Peace: An } \\
\text { Environmental Perspective }\end{array}$ & Don Mayer & Jan. 2002 \\
\hline No. 429: Why do Governments Privatize? & $\begin{array}{l}\text { Loren Brandt, Hongbin Li, and } \\
\text { Joanne Roberts }\end{array}$ & Dec. 2001 \\
\hline No. 428: Testing Russia's Virtual Economy & Vlad Ivanenko & Dec. 2001 \\
\hline No. 427: War and the Business Corporation & Eric W. Orts & Dec. 2001 \\
\hline $\begin{array}{l}\text { No. 426: Partial Privatization and Firm Performance: Evidence from } \\
\text { India }\end{array}$ & Nandini Gupta & Dec. 2001 \\
\hline $\begin{array}{l}\text { No. 425: Direct Foreign Investments and Productivity Growth in } \\
\text { Hungarian Firms, 1992-1999 }\end{array}$ & Jérôme Sgard & Nov. 2001 \\
\hline $\begin{array}{l}\text { No. 424: Banking Passivity and Regulatory Failure in Emerging } \\
\text { Markets: Theory and Evidence from the Czech republic. }\end{array}$ & Jan Hanousek and Gerard Roland & July 2001 \\
\hline $\begin{array}{l}\text { No. 423: Conceptions of the Corporation and the Prospects of } \\
\text { Sustainable Peace }\end{array}$ & Jeffrey Nesteruk & Dec. 2001 \\
\hline No. 422: The Role of the Corporation in Fostering Sustainable Peace & Timothy Fort and Cindy Schipani & Nov. 2001 \\
\hline No. 421: Wage Arrears and the Distribution of Earnings in Russia & $\begin{array}{l}\text { Hartmut Lehmann and Jonathan } \\
\text { Wadsworth }\end{array}$ & Dec. 2001 \\
\hline $\begin{array}{l}\text { No. 420: Transferring Collective Knowledge: Collective and } \\
\text { Fragmented Teaching and Learning in the Chinese Auto Industry }\end{array}$ & $\begin{array}{l}\text { Jane Zhou, Jaideep Anand, and } \\
\text { Will Mitchell }\end{array}$ & Dec. 2001 \\
\hline $\begin{array}{l}\text { No. 419: Liberalization, Corporate Governance, and the Performance of } \\
\text { Newly Privatized Firms }\end{array}$ & $\begin{array}{l}\text { Narjess Boubakri, Jean-Claude } \\
\text { Cosset, and Omrane Guedhami }\end{array}$ & Dec. 2001 \\
\hline $\begin{array}{l}\text { No. 418: The European Data Privacy Directive and International } \\
\text { Relations }\end{array}$ & Steven R. Salbu & Dec. 2001 \\
\hline $\begin{array}{l}\text { No. 417: Capital Markets and Capital Allocation: Implications for } \\
\text { Economies in Transition }\end{array}$ & $\begin{array}{l}\text { Artyom Durnev, Randall Morck, } \\
\text { and Bernard Yeung }\end{array}$ & Dec. 2001 \\
\hline $\begin{array}{l}\text { No. 416: Forthcoming in: The Journal of Economic Perspectives, "Data } \\
\text { Watch. Research Data from Transition Economies," 16(2) Feb. } 2002 .\end{array}$ & $\begin{array}{l}\text { Randall K. Filer and Jan } \\
\text { Hanousek }\end{array}$ & Dec. 2001 \\
\hline $\begin{array}{l}\text { No. 415: Forthcoming in: The Journal of Economic Perspectives, } \\
\text { "Transition Economies: Performance and Challenges," 16(2) Feb. } 2002 .\end{array}$ & Jan Svejnar & Dec. 2001 \\
\hline $\begin{array}{l}\text { No. } 415 \text { Forthcoming in: The Journal of Economic Perspectives, } \\
\text { "Transition Economies: Performance and Challenges," 16(2) Feb. } 2002 .\end{array}$ & Jan Svejnar & Dec. 2001 \\
\hline $\begin{array}{l}\text { No. } 414 \text { Forthcoming in: The Journal of Economic Perspectives, "The } \\
\text { Great Divide and Beyond: Financial Architecture in Transition," 16(2) } \\
\text { Feb. } 2002 .\end{array}$ & Erik Berglof and Patrick Bolton & Dec. 2001 \\
\hline
\end{tabular}

